\title{
月六年一十二治 明
}

河モ 㜢 杂 部 I 學

內 登, 年郡投士

國見遗 至川 $川$ モ

高

安

郡

塚

遭

遭

䨘

見

事

$n \Rightarrow$ 坪 村 $=$

ア探 茾 $=$ 日

りり君散本

シ モ西在塚

カ1遊七穴

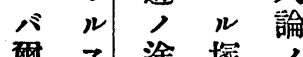

后氏沀宗一

再, 八二篇

探未幸就
ス 跡局諸

> $\Rightarrow *$ 以

念記君其齐

勃載 $=$ 所 $=1$

卜七尾見河土

シ ザシ $₹$ 队

$\nabla り$ 此述國

禁 シ 地 髚三直

ス 新 $¥ 刃$ 安 ン 方
談を夜ざ

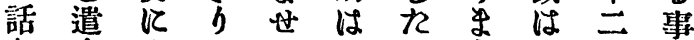

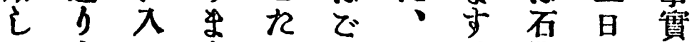
○て 來てすの音

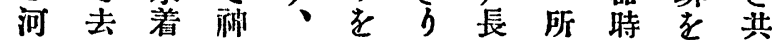
內 らの

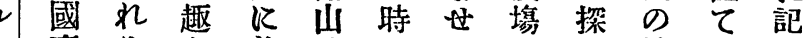
大高まを着陵のん外遗具載 安し通、を湎で行ま跡账致

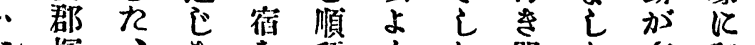

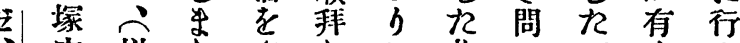

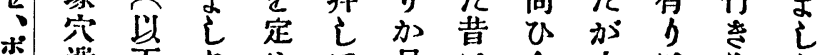

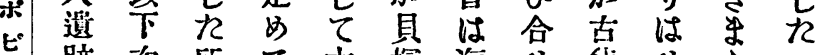
跡次所て大塚海世代世它

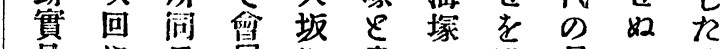

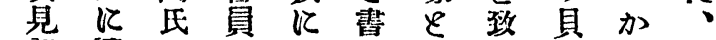
記瀷は佳歸きき書乞塚と地

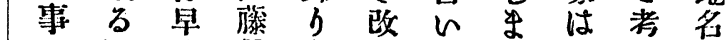

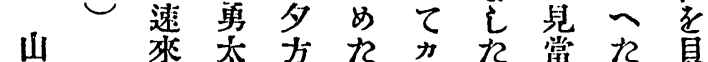
崎 訪 郎崴 深氏車の $ッ$ 何ま ら

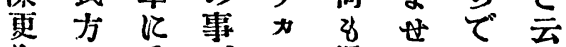

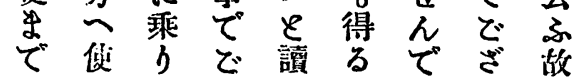

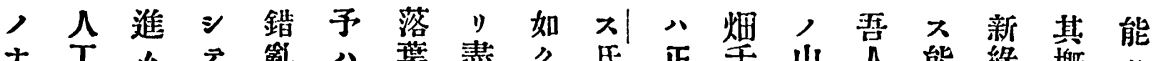

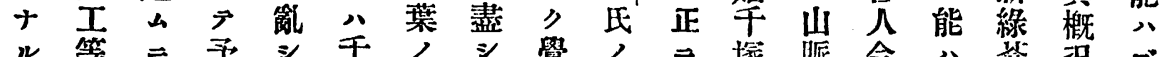

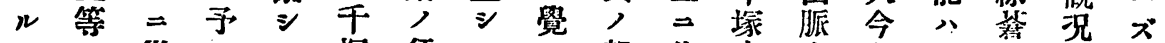

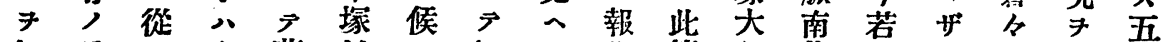

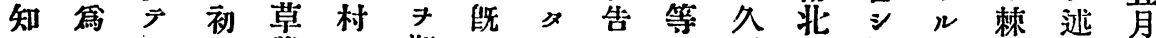

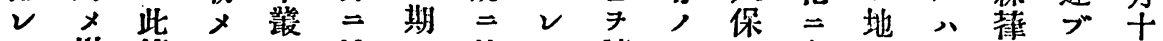

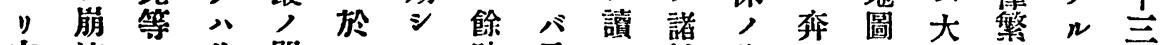

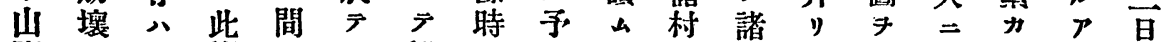

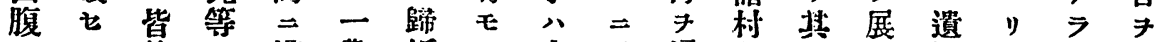

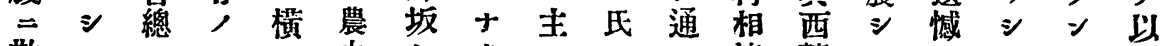

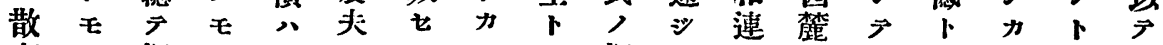
在人塚ノル

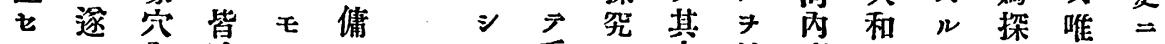

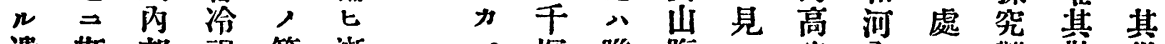

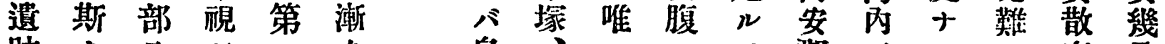

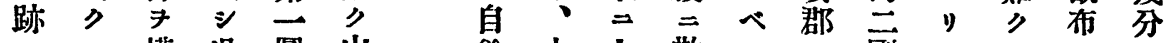

三八川戬 過 圖山

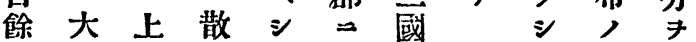
其殘造キ, 腹年訅布而於ノ

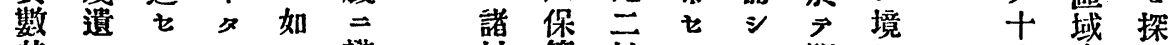
甚 女 ル リ * 攀 村 等 村 リ 多

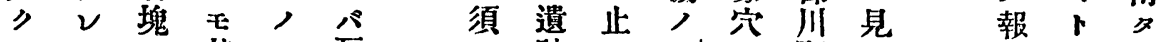
シ > 其 ア

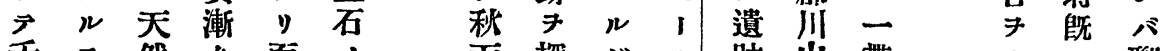

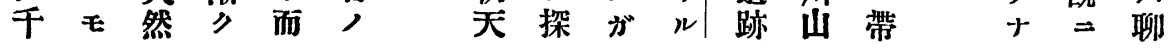


號入十二第誌雑會學類八京東

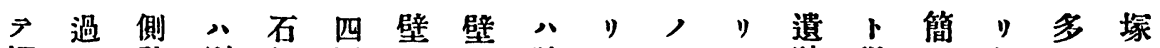

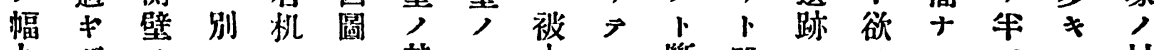

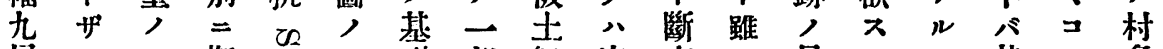

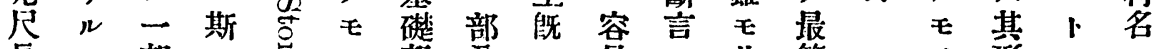

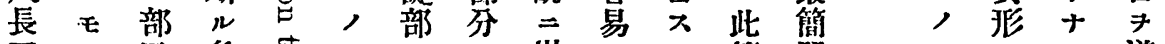

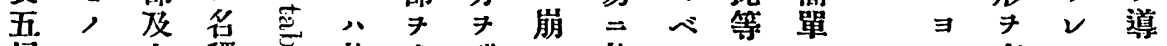
尺十之稱畐其成殘之其力八广存心 訛 $=7$, 形 $大$ 遺天遭 $ラ$ 唯 $n$ 溯 + 而截舆稱猋所

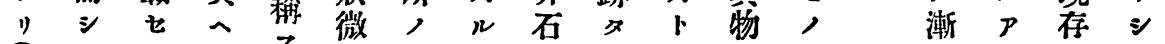

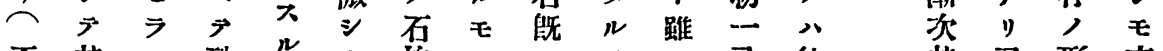
石其 2 殊 者”塊, $=7$ 已彼其及形亦

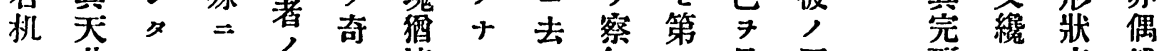

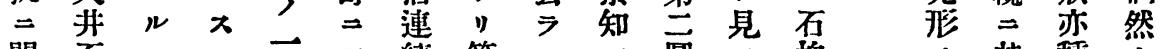

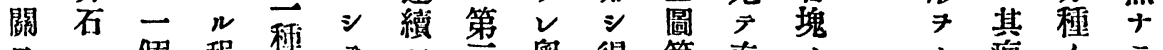

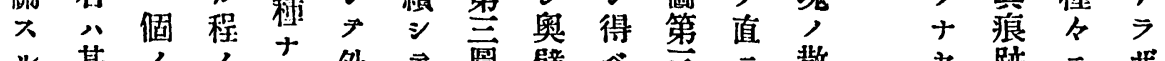

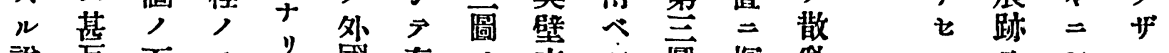

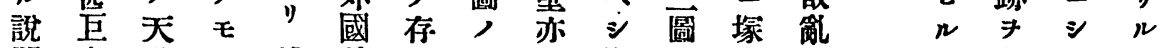
明大韭, 然某 $て ゙ モ$ 既即, 穴七留 $\overrightarrow{7}$ 八 $才$ 石 $=$ 》地 $n,=$ 第如,, , 完如

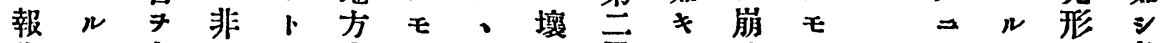

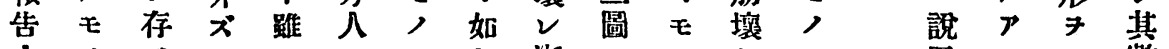

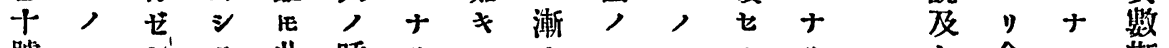
號 坪 $シ=$ 唯等 $匚$ 第周 側

經 被 第 $九$ 侧第孔、第 圭十 $n$, 壁杂 7 十分人灭露等, 被漸圖モ徃, 圖殘

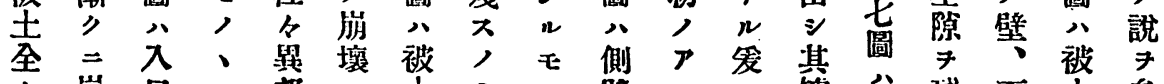

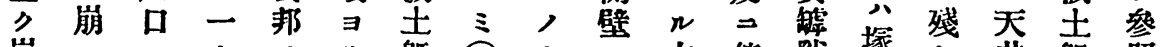
崩 $\| \vec{r}, y$ 書出 $\Rightarrow$ 公 、天室誌入全，县部石心蔀石崩レ 二井 $=$ 万”石;破塊人肉二 於石至散心崩石入壤間物部》

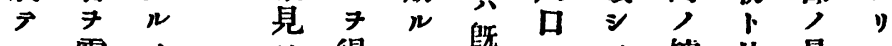
八露, 万得、既风元此景

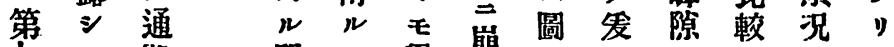

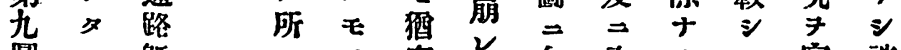

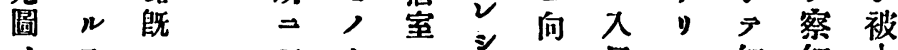

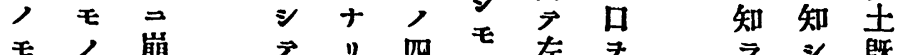

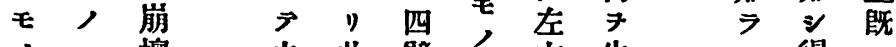
人 壤之此壁方方生得二

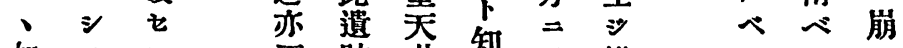
如 $\vec{\nabla}$ 石跡并知 $\vec{\nabla}$ 樵 $三 \equiv$

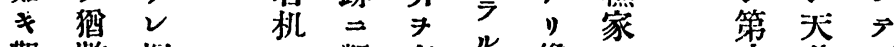

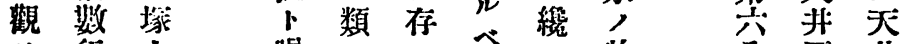

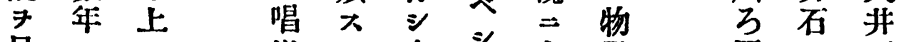
呈 $\ni$ 道

河 内 國 高 郡 塚 遗 跡 貶 見 能 事

塊壤

$\leadsto$ 七

傾 三

斜 $モ$

不 唒

整 石

厂室

1. 概

踓 形

E 7

其 存

等七

間

獭 
月六年一十二治明

河

内

國

高

安

郡

家

连

跡

見

レシ阜異べ予こ覆

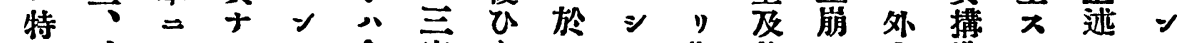
$=$ 人

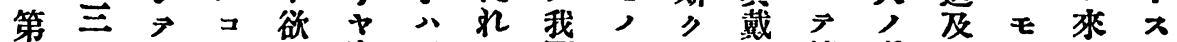

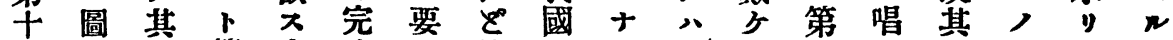
$\Rightarrow \Rightarrow$ 南第完全 圖於腹十全ナザ國てャル天圖ル傍りモノ

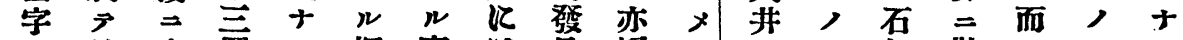

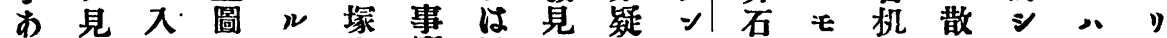
水 $几$ 口

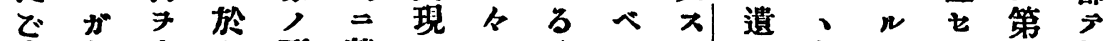
山如有与 形就 塚”ジル 狀 $* レ$ 述の

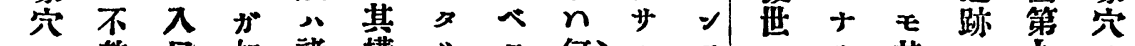

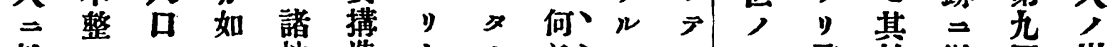

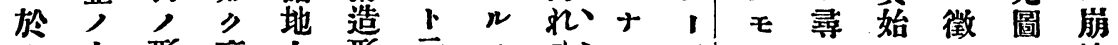

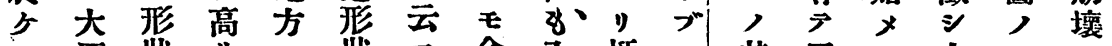

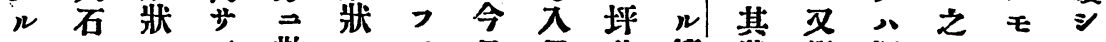
モ $\ni$ 三 散

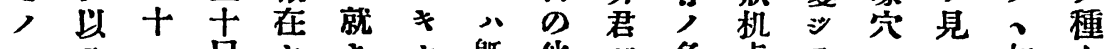

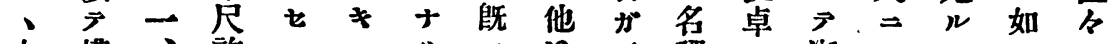

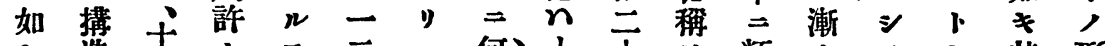

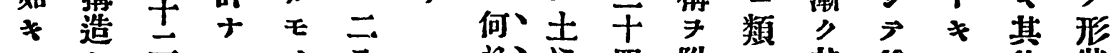

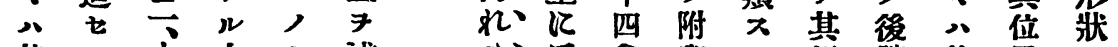

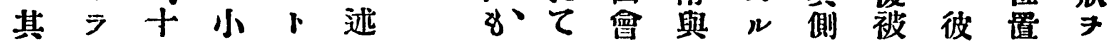

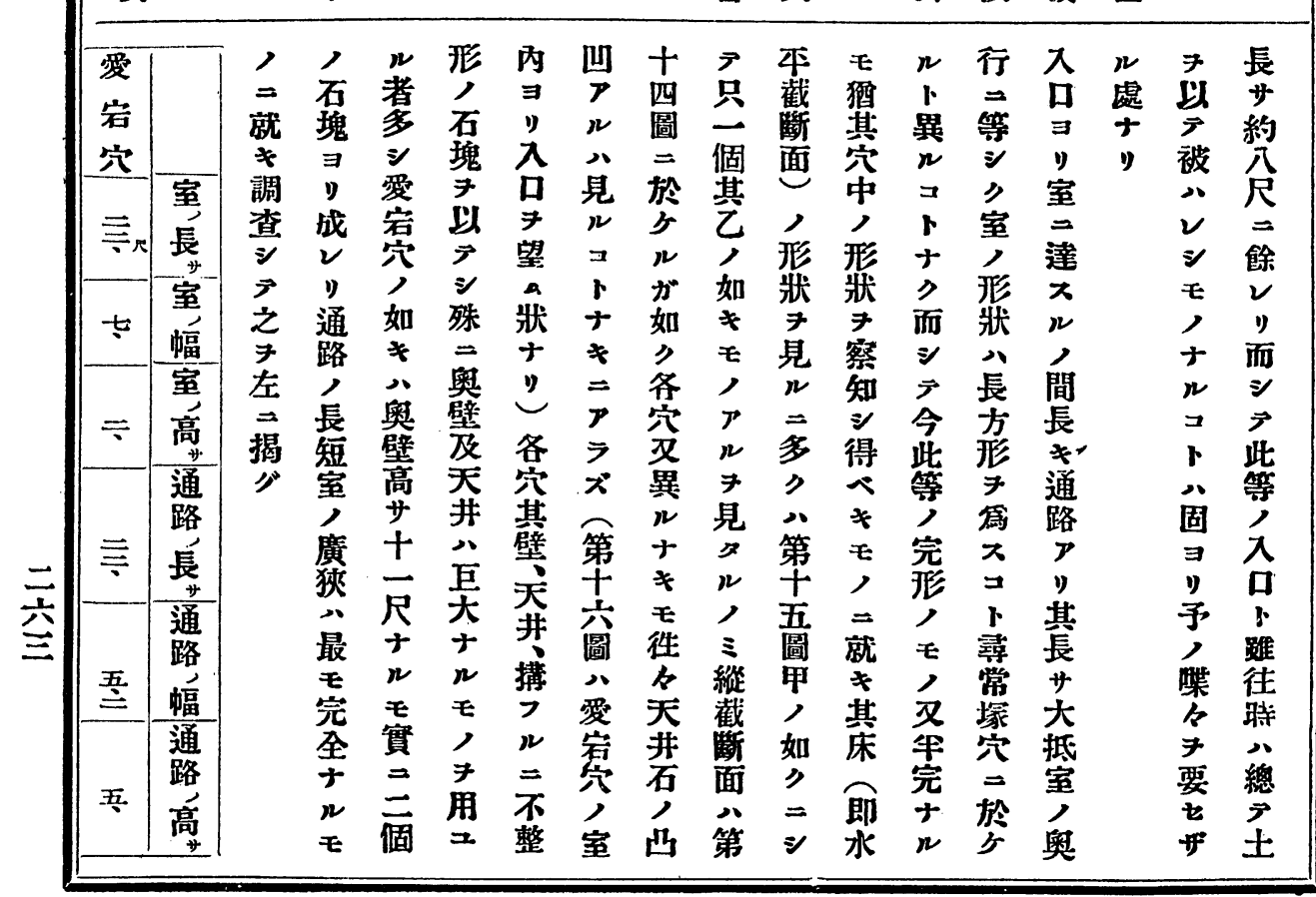




\section{圖一第}
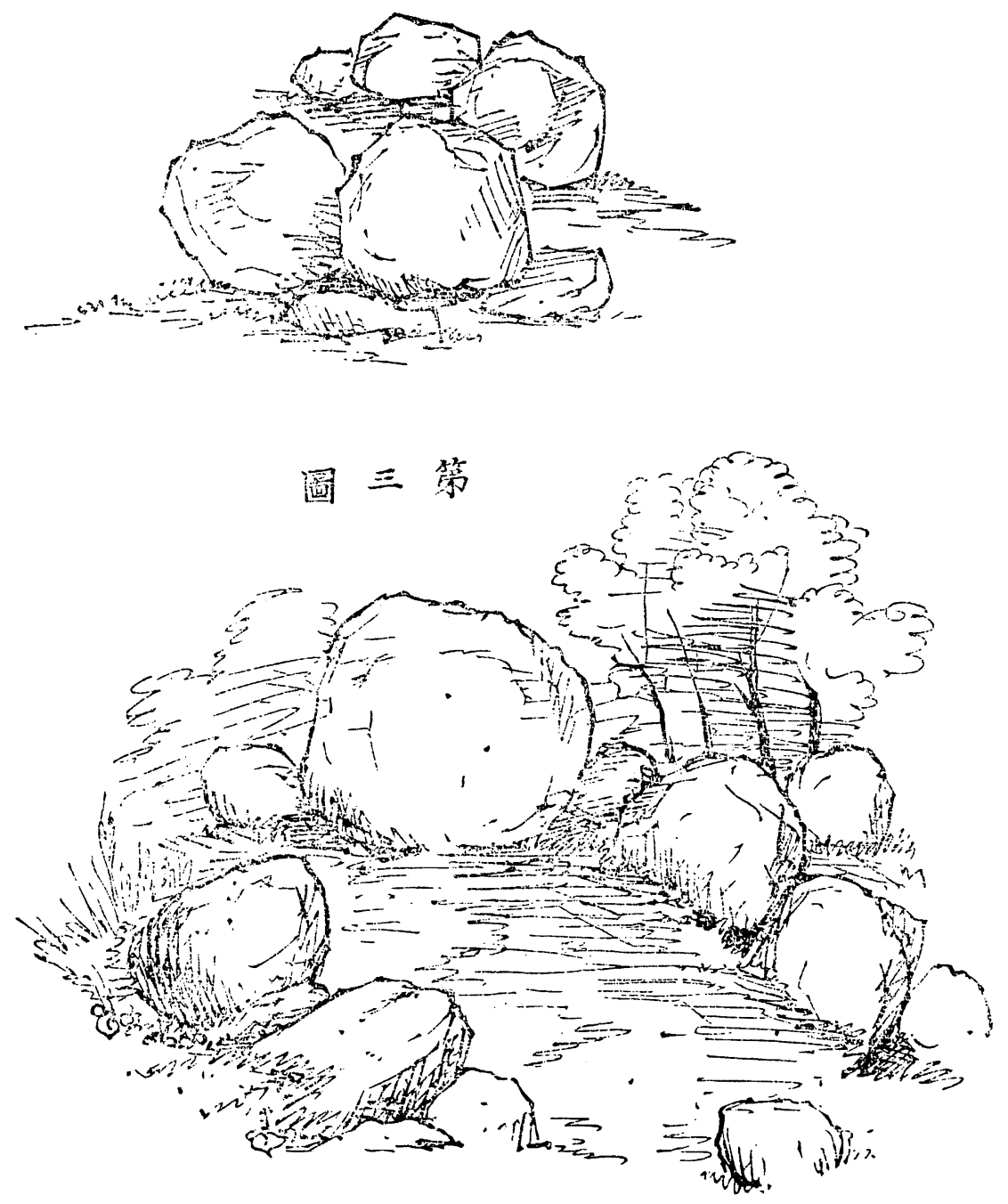


\section{月亲年一十二治明}

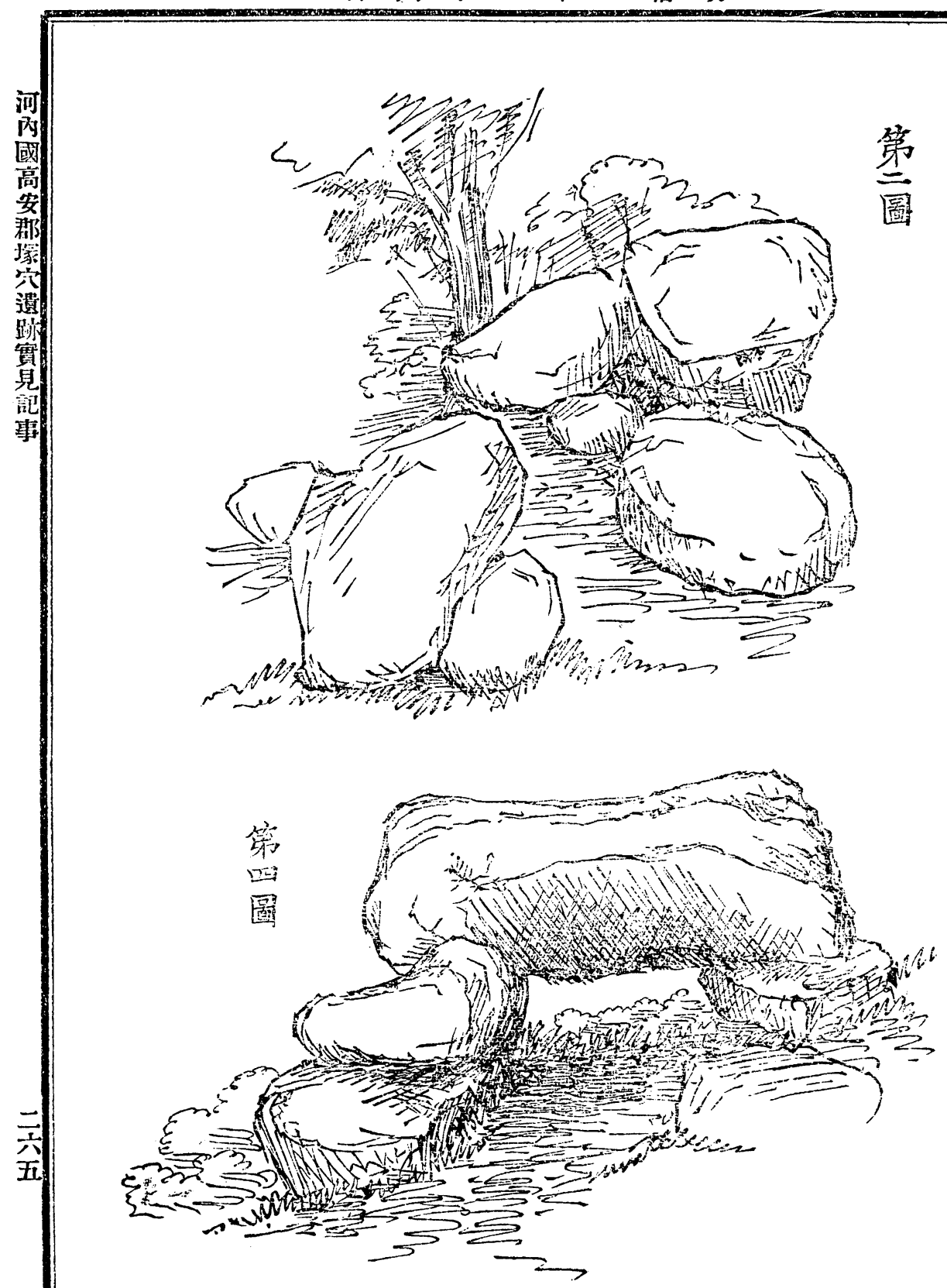




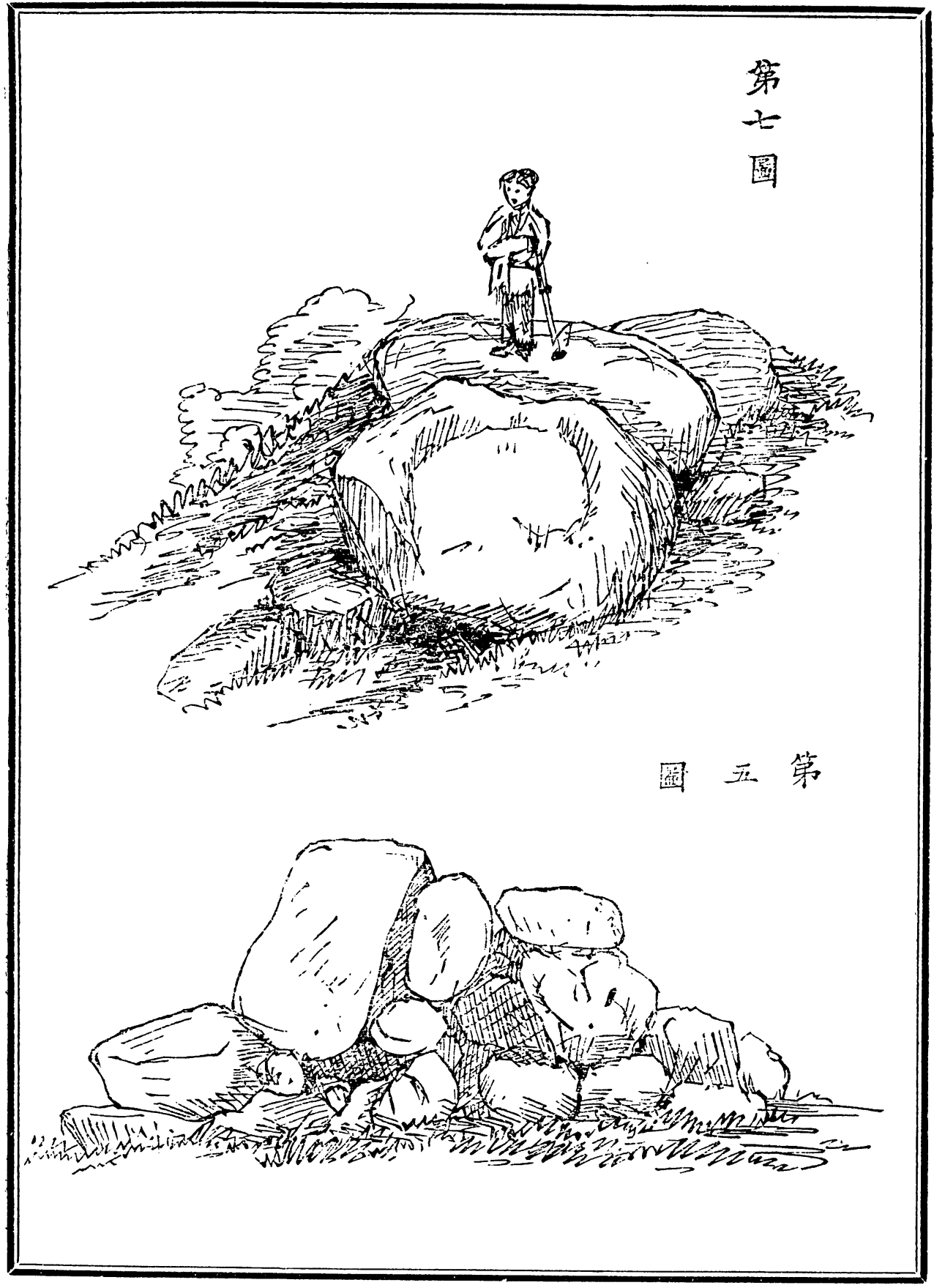

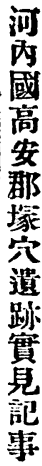

交 


\section{月六年一十三治明}

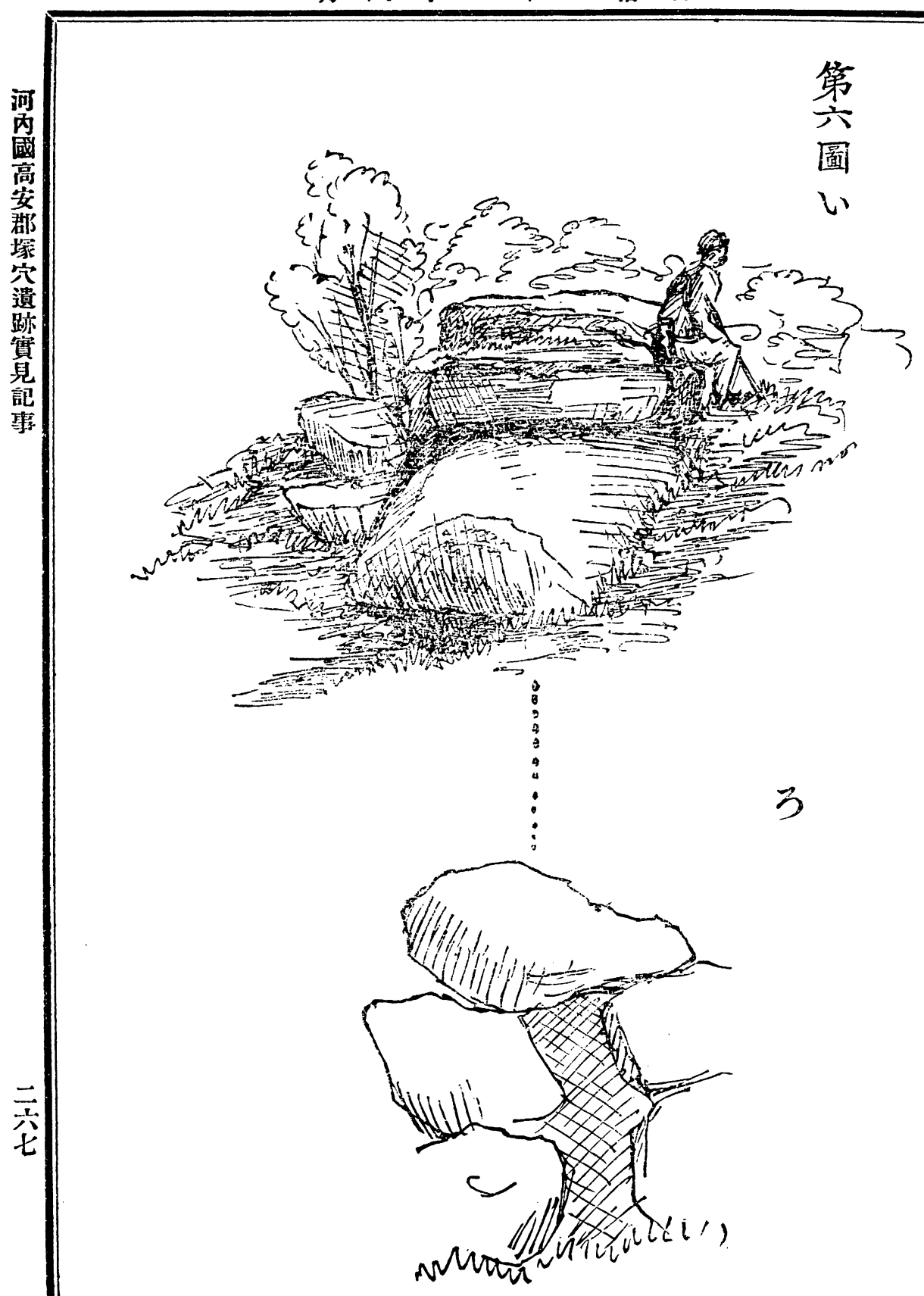


號入十二第誌雜會學類八京東

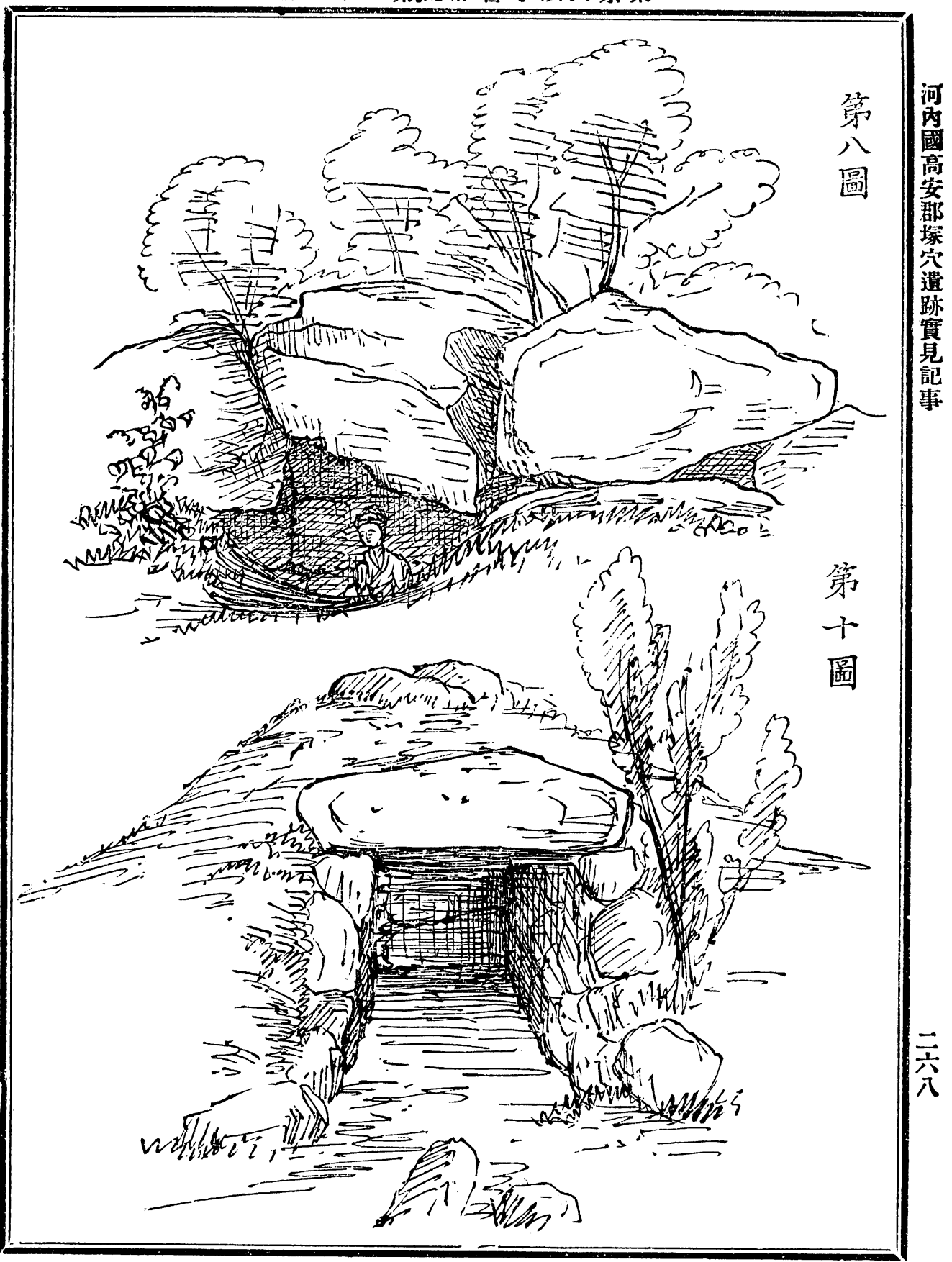




\section{月六年 -+ 二治明}

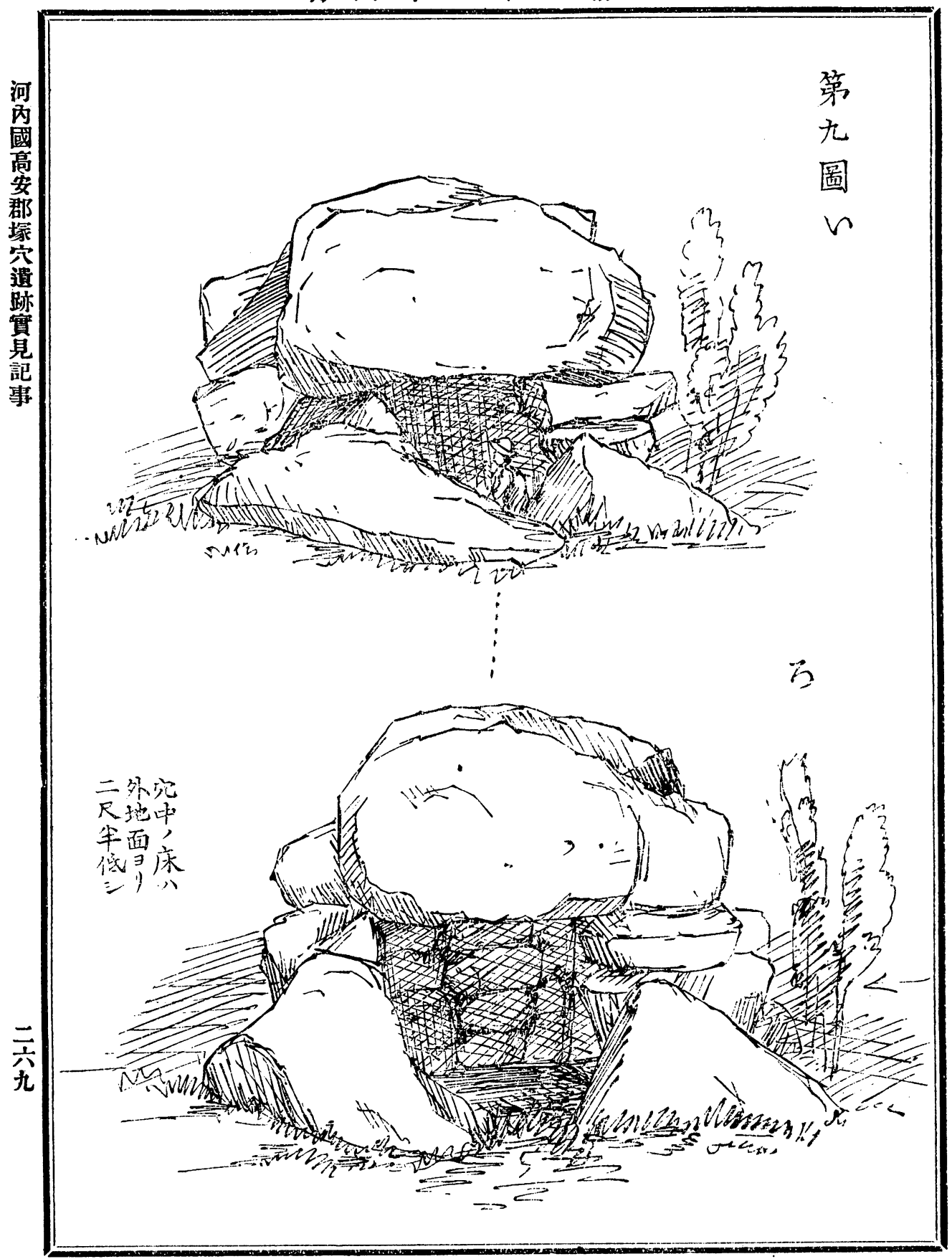



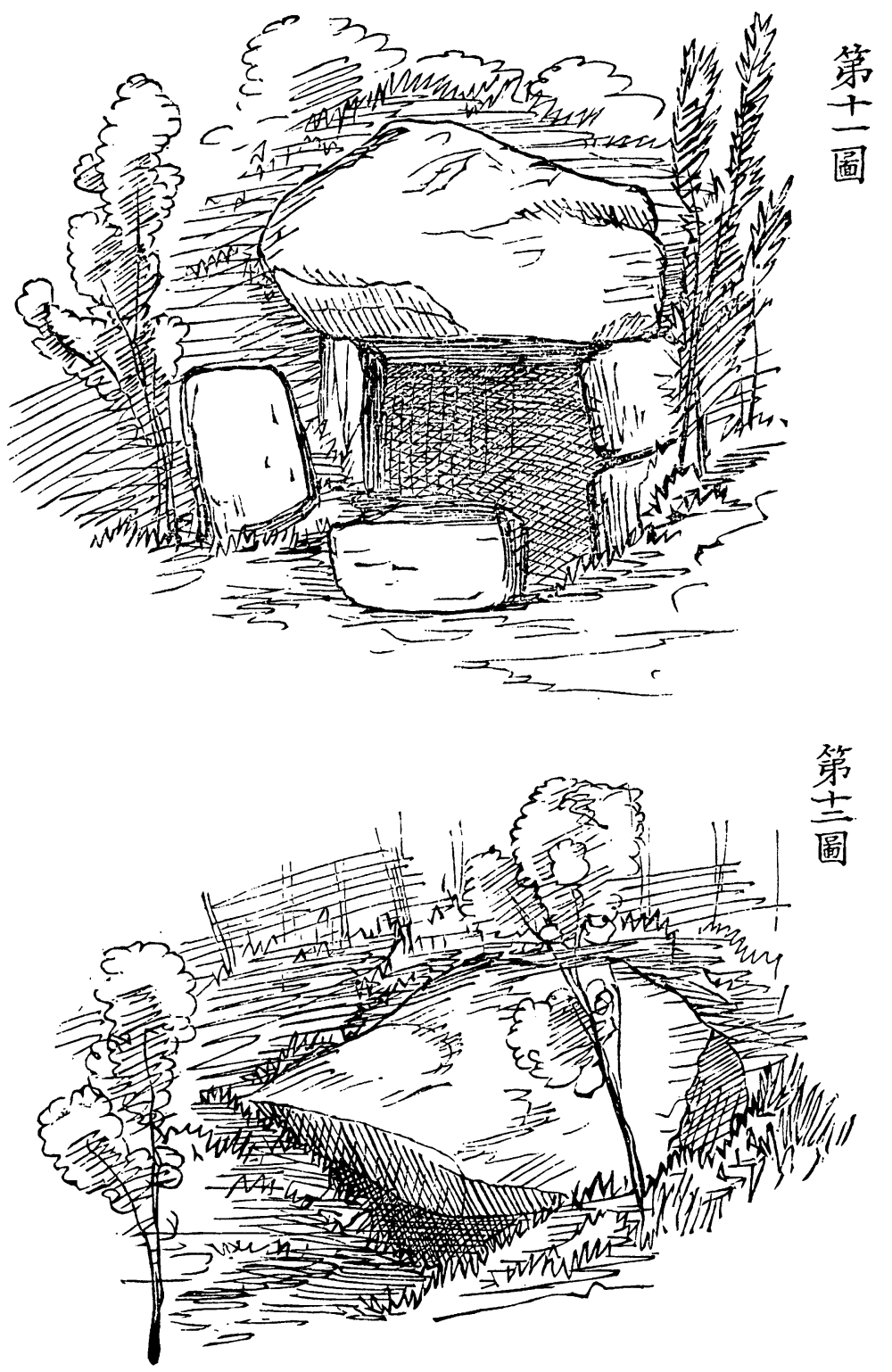
號入十二第誌雉會學類人京東

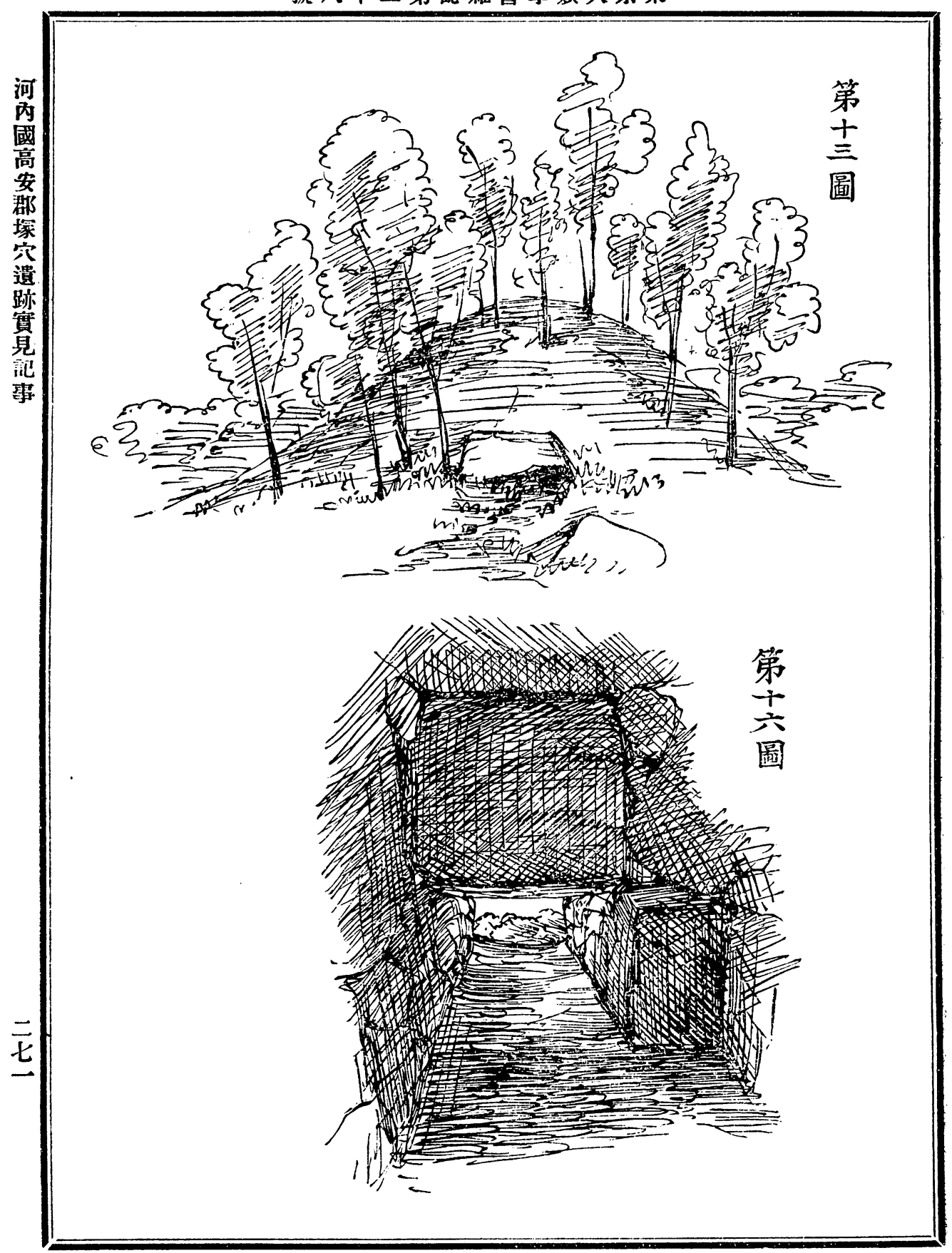




\section{月六年一十二治 明}

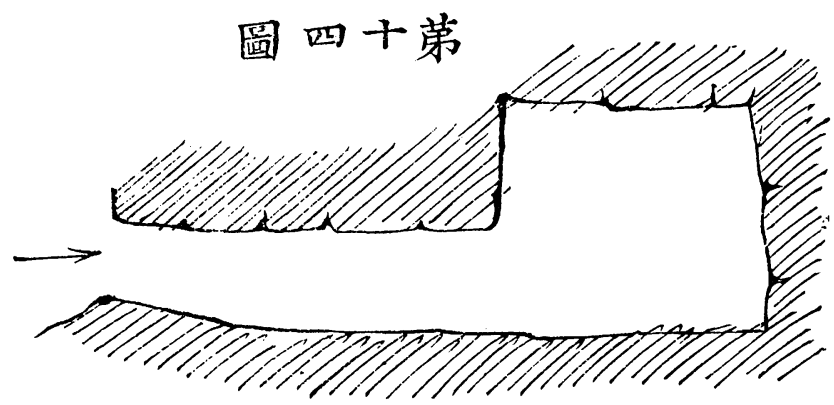

圆五十苟
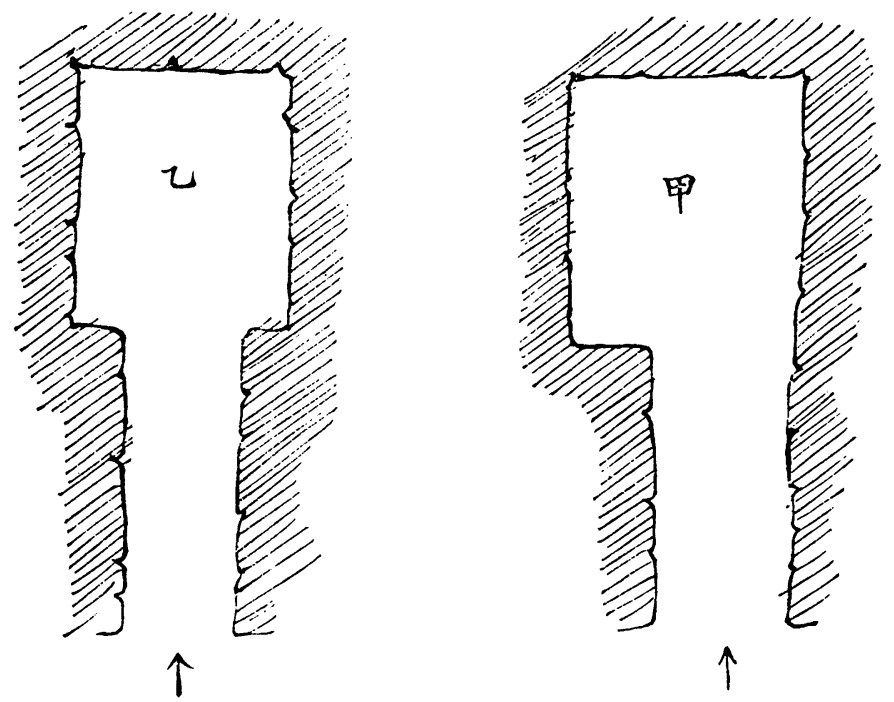
月六年 一十二治 明

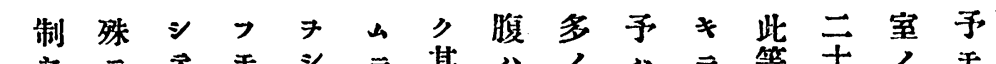

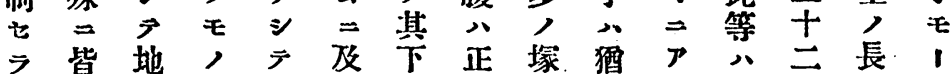

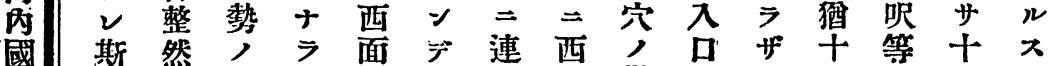
高》南不ンシ八》面散三分，四民

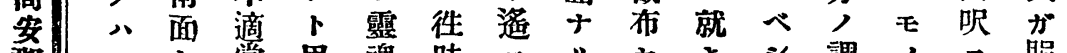

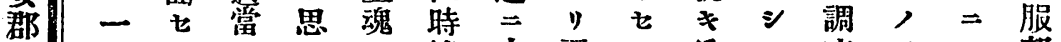

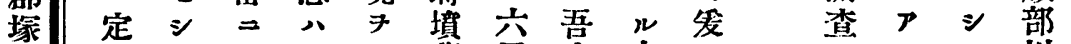

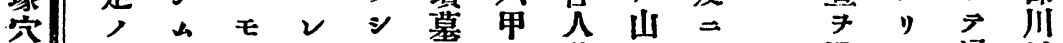
遺 規 $x$ 關 $シ \overrightarrow{7}$, 若豚一逐 $\vec{*}$ 通村 跡 律 モを 三 此此悛 シ八言

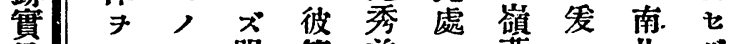
見 + 八眼 等美 $=$ 茅 記。其界只, 搆海登三 事 モ神陝 $\vec{*}$ 光路 $シ 2$ 得

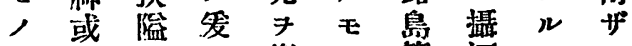
$\tau \nu+=$ 樂, 等河 $₹$ $\overline{7}$ ， 入 $\rightarrow$ 必, $=$ 種 $=$ 口 $三$ 公好州 $=$ y

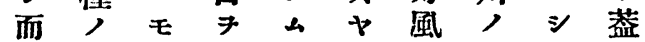
安係撰儿其光本 $\vec{\nabla}$

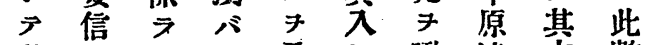

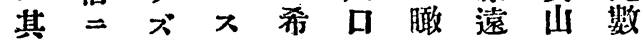

分予路=

而吕三於

煎士

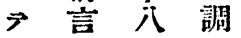

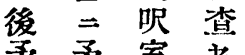

予柔室

誤茫廣

$\exists \pi$ 吹狹

正

入 如 $シ 7$

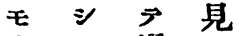

亦 1 通

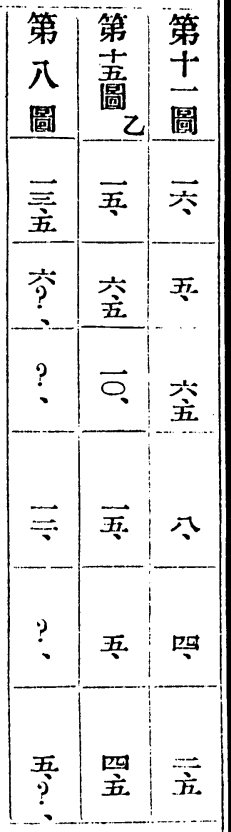

具 $\exists$ 見途誌 $n=$ 明

村》刀男三蓝至治 迄直》中記 分克紫村 $九$ 奎間士 里十近如 $=$ 兵路年總 涂九譈 $\approx$ 、上傍五下 其里 $\exists$ 其”, 左月總

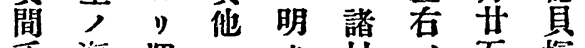
千游葷人》村, 五塚 葉溜搬墸す具兵星巡

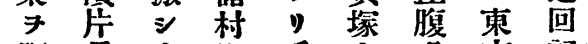
距具承道千存處京記 几村》路葉在々 7 $+= \pm \Rightarrow \neq$ 七 $=$ 發 数至モ古經儿具

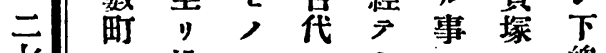
壱 , 投

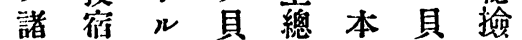
村え心筑菄會露县林 ヨ東 $三 \quad$ 金第出川

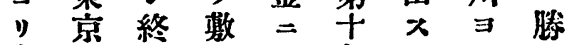

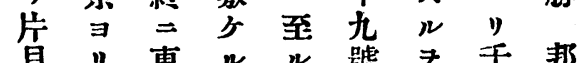
森片金 $\nsucceq$, 猚見亲

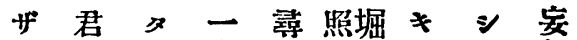
ルヨッ片邓報泟入信 ベリアル ル告, 其 シ 會 $n$ 遺モショ、辛實 員, 物一參考福

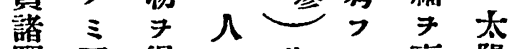
賢而得飞此ル拧陽 $=シ$ 知等ナ少 7 示 $テ+ル 户 り$ サ此》モ塚 人等唯, 穴載此, 至 刃近ナヨ七說意尊 レ土傍シ リ $⿻ コ 一$ バ器, 支坪理出聖 予 八徑予器井學》> 八既 路 モ 物 正協りモ 亦 = 畔塚, 五會、, 贅貴間穴出郎暃云卜 言 曾 $=$ 中 $ッ$ 君誌 フ $\exists \Rightarrow$ 朝 $\neq$ 第, 永 費遥鮮探、足四䛊久 大笴主》 7 利十 $=$ 之 キ $シ$ 器 タ 村古参歸 要 若 $\ni$ 民埥三ス面 せ林得モき發記心た 